\title{
Assessment of genetic mutations in the $X R C C 2$ coding region by high resolution melting curve analysis and the risk of differentiated thyroid carcinoma in Iran
}

\author{
Shima Fayaz ${ }^{1,2^{*}}$, Pezhman Fard-Esfahani ${ }^{2, *}$, Armaghan Fard-Esfahani ${ }^{3}$, Ehsan Mostafavi ${ }^{4}$, Reza Meshkani ${ }^{1}$, \\ Hossein Mirmiranpour ${ }^{1}$ and Shahnaz Khaghani ${ }^{1}$ \\ ${ }^{I}$ Department of Biochemistry, Faculty of Medicine, Tehran University of Medical Sciences, Tehran, Iran. \\ ${ }^{2}$ Department of Biochemistry, Pasteur Institute of Iran, Tehran, Iran. \\ ${ }^{3}$ Research Institute for Nuclear Medicine, Tehran University of Medical Sciences, Tehran, Iran. \\ ${ }^{4}$ Department of Epidemiology, Pasteur Institute of Iran, Tehran, Iran.
}

\begin{abstract}
Homologous recombination (HR) is the major pathway for repairing double strand breaks (DSBs) in eukaryotes and $\mathrm{XRCC2}$ is an essential component of the HR repair machinery. To evaluate the potential role of mutations in gene repair by HR in individuals susceptible to differentiated thyroid carcinoma (DTC) we used high resolution melting (HRM) analysis, a recently introduced method for detecting mutations, to examine the entire XRCC2 coding region in an Iranian population. HRM analysis was used to screen for mutations in three XRCC2 coding regions in 50 patients and 50 controls. There was no variation in the HRM curves obtained from the analysis of exons 1 and 2 in the case and control groups. In exon 3, an $\mathrm{Arg}^{188} \mathrm{His}$ polymorphism (rs3218536) was detected as a new melting curve group (OR: $1.46 ; 95 \% \mathrm{Cl}: 0.432-4.969 ; \mathrm{p}=0.38$ ) compared with the normal melting curve. We also found a new $\mathrm{Ser}^{150} \mathrm{Arg}$ polymorphism in exon 3 of the control group. These findings suggest that genetic variations in the XRCC2 coding region have no potential effects on susceptibility to DTC. However, further studies with larger populations are required to confirm this conclusion.
\end{abstract}

Key words: DNA repair, gene polymorphism, mutation analysis.

Received: June 12, 2011; Accepted: October 5, 2011.

\section{Introduction}

Thyroid cancer is the most common endocrine malignancy and its incidence has increased in recent years (Leenhardt et al., 2004; Davies and Welch, 2006; Jemal et al., 2008). Differentiated thyroid carcinoma (DTC) is the most common type of all thyroid carcinomas (accounting for $\sim 90 \%$ of all cases) and consists of papillary, follicular and Hürthle cell carcinomas, the latter being a subtype of follicular thyroid carcinoma (Hundahl et al., 1998). Risk factors associated with DTC include exposure to various carcinogenic agents, ethnicity and dietary habits, although exposure to ionizing radiation is still the only recognized risk factor (Ron et al., 1995; Xiong et al., 2005; Preston et al., 2007).

Recent studies have proposed that genetic variation in conserved DNA repair systems may influence susceptibility to cancer (Gatzidou et al., 2010). These systems nor-

Send correspondence to Shahnaz Khaghani. School of Medicine, Tehran University of Medical Sciences \& Health Services, Poursina ST, PO Box 14155-6447 Tehran, Iran. E-mail: khaghani@tums.ac.ir.

*These authors contributed equally to this work. mally ensure the genetic intactness of cell populations such that any alteration in the genes related to these systems could lead to a defect in DNA repair pathways and ultimately affect the cellular genetic stability and susceptibility to cancer. In severe DNA damage, such as double-strand breaks (DSBs), there are two important recombination systems for cell survival, namely, homologous recombination (HR) and non-homologous end joining (NHEJ) (Paques and Haber, 1999; Peterson and Cote, 2004).

In eukaryotes, HR is the major pathway for DSB repair and has an important role in preventing mutations, chromosomal instability and cancer; these functions make HR essential for cell viability and genomic stability (Jackson, 2002; Thompson and Schild, 2002). The HR repair system functions primarily during the S and G2 phases of the cell cycle. Since HR is an error-free pathway of damage tolerance that allows the replication bypass of lesions during a template switch it has a distinct advantage over NHEJ (Jackson, 2002; Thompson and Schild, 2002).

The RAD51 gene family is the key component of HR and its impairment can lead to extreme sensitivity to certain DNA damaging agents, intense genomic instability and a 
risk of cancer (Sonoda et al., 1998; Cui et al., 1999; Deans et al., 2000, 2003; Takata et al., 2001; Gruver et al., 2005; Siraj et al., 2008). The RAD51-like gene family in somatic mammalian cells is composed of XRCC2, XRCC3, RAD51L1, RAD51L2 and RAD51L3 (Thacker, 1999). There are indications that XRCC2 has an important role in enhancing the action of RAD51, with a loss of XRCC2 delaying the early steps of HR, including the integration of RAD51 at the site of DNA damage, nucleoprotein filament formation and strand invasion (Sugawara et al., 2003; Wolner et al., 2003). In XRCC2-deficient cells, RAD51 responses are reduced by approximately five-fold, and this has led to $X R C C 2$ being recognized as a repair responseenhancing factor (Tambini et al., 2010).

$X R C C 2$ is a $29,668 \mathrm{~kb}$ gene located on human chromosome 7q36.1 and consists of three exons (1 to 3 ) that contain 38,82 and $722 \mathrm{bp}$, respectively. XRCC2 protein is highly conserved among mammalian species (Tambini et al., 2010). Several studies have examined the association between genetic polymorphisms in XRCC2 and different cancers (Han et al., 2004; Jiao et al., 2008; Curtin et al., 2009). In the present report, we describe the first case-control study of an Iranian population to examine the association between mutations in the entire coding region of the XRCC2 gene and individual susceptibility to DTC based on high resolution melting (HRM) analysis, a recently introduced method for detecting mutations (Montgomery et al., 2010).

\section{Materials and Methods}

\section{Study subjects}

A sample size calculation (Kasiulevicious et al., 2006) indicated that the minimum sample size for this case-control study was $\sim 45$ for each group (controls and cases). In addition, the minimum odds ratio (OR) for significance was $2.5(\mathrm{p}<0.05)$. The probability of having a mutant allele in the XRCC2 coding region in control individuals was estimated as 0.35 . Based on these preliminary calculations, our study population consisted of 50 patients with histopathologically confirmed DTC and 50 controls. Informed consent was obtained from all participants before commencement of the study and the study was approved by the ethics committee of Tehran University of Medical Science. The DTC patients were recruited from the Research Institute for Nuclear Medicine of Shariati Hospital, Tehran, Iran. The control population was matched for age $(\leq 50$ and $>50$ year) and sex, with no previous or concurrent malignant disease. The controls were recruited from volunteers at two academic centers in Tehran. Individuals with a history of other cancers, radiation exposure, alcohol consumption or smoking were excluded from the study.

\section{DNA extraction}

$5 \mathrm{~mL}$ of peripheral blood was collected from each subject into tubes containing $1 \mathrm{~mL}$ of EDTA $(1 \mathrm{~g} / \mathrm{dL})$ and stored at $-20{ }^{\circ} \mathrm{C}$ until used. Whole blood DNA was extracted by a salting out procedure (Miller et al., 1988).

\section{Primer design and assay conditions for PCR-HRM}

One primer pair for exon 1 (Ex1), three primer pairs for exon $2(E x 2)$ and three primer pairs for exon $3(E x 3)$ were used in this work (Table 1). PCR-HRM was done in a Rotor-Gene 6000 real-time rotary analyzer (Corbett Life Sciences). The reactions were prepared in $10 \mu \mathrm{L}$ volumes in $0.1 \mathrm{~mL}$ strip tubes of a 72 -well rotor. For symmetric PCR-HRM, the amount of DNA in each reaction was adjusted to $50 \mathrm{ng}$. Each reaction contained $5 \mu \mathrm{L}$ of $2 \times \mathrm{HRM}$ PCR Master Mix (Type-it HRM PCR kit, QIAGEN), $0.7 \mu \mathrm{L}(10 \mu \mathrm{M})$ of primer mix, $1.5 \mu \mathrm{L}(50 \mathrm{ng})$ of DNA and DNA RNase-free water to a final volume of $10 \mu \mathrm{L}$.

The PCR cycling profile is summarized in Table 1. After amplification, HRM analysis data were collected from $65^{\circ} \mathrm{C}$ to $85^{\circ} \mathrm{C}$, with each step raised by $0.05^{\circ} \mathrm{C}$, followed by a waiting time of $10 \mathrm{~s}$. Samples from the top, middle and bottom of each melting curve group and suspicious melting curves were sequenced. Any new mutation detected by PCR-HRM was screened for in the other samples by using the Allele Refractory Mutation System (ARMS). The ARMS primers and fragment lengths are listed in Table 1 .

\section{Statistical analysis}

Hardy-Weinberg equilibrium of the XRCC2 alleles in the control population was assessed using the Chi square test $\left(\chi^{2}\right)$. The homogeneity of age distribution between the controls and cases was assessed with an independent sample $t$-test and Levene's test. Allelic and genotypic frequencies were compared across groups using the Chi square test. The odds ratio (OR) and the corresponding 95\% confidence intervals (CIs) between DTC and a detected polymorphism were calculated using logistic regression. All analyses were done with SPSS v13 software.

\section{Results}

This study included 50 DTC patients and 50 cancer-free controls. The two groups were matched for sex and age ( $\leq 50$ and $>50$ years). The mean age ( \pm SEM) in the cases and controls was $38.4 \pm 2.1$ and $36.2 \pm 1.2$ years, respectively. Age and sex were not significantly different between the two groups. The general characteristics of both groups are shown in Table 2.

\section{HRM analysis results}

HRM analysis showed no variations in the melt phase analysis curves for the Ex1, Ex2a, Ex2b, Ex2c, Ex3a and Ex3c fragments in the case and control groups. A new melting curve group was detected in the Ex3b fragment compared to the normal melting curves retrieved from the wild type genotype group (Figure 1). To confirm the existence of 
Table 1 - (A) Primers for the XRCC2 coding regions and the PCR conditions used before HRM analysis. (B) Primers used in PCR-ARMS.

\begin{tabular}{|c|c|c|c|}
\hline Exon number & Primer ( $5^{\prime}$ to $\left.3^{\prime}\right)$ & Amplicon size (bp) & PCR conditions \\
\hline \multicolumn{4}{|l|}{ A } \\
\hline Exon1 (Ex1) & $\begin{array}{l}\text { F: TATTGCGCATGCTCCCGCC } \\
\text { R: CCAATCCCCCGGGTTCCC }\end{array}$ & 277 & $\begin{array}{l}95^{\circ} \mathrm{C}, 5 \mathrm{~min} ; 45 \text { cycles }\left(95^{\circ} \mathrm{C}, 10 \mathrm{~s} ; 64{ }^{\circ} \mathrm{C}, 30 \mathrm{~s} ; 72{ }^{\circ} \mathrm{C} \text {, }\right. \\
16 \mathrm{~s}) ; 72{ }^{\circ} \mathrm{C}, 5 \mathrm{~min}\end{array}$ \\
\hline Exon2a (Ex2a) & $\begin{array}{l}\text { F: GGTATAAATATAGATGTCTAGG } \\
\text { R: GGTTCTATTTCTTTCAG }\end{array}$ & 118 & $\begin{array}{l}95^{\circ} \mathrm{C}, 5 \mathrm{~min} ; 45 \text { cycles }\left(95^{\circ} \mathrm{C}, 10 \mathrm{~s} ; 52{ }^{\circ} \mathrm{C}, 30 \mathrm{~s} ; 72{ }^{\circ} \mathrm{C} \text {, }\right. \\
16 \mathrm{~s}) ; 72{ }^{\circ} \mathrm{C}, 5 \mathrm{~min}\end{array}$ \\
\hline Exon $2 b($ Ex $2 b)$ & $\begin{array}{l}\text { F: ССTTCTCTCTTCTTTTATAAGC } \\
\text { R: ACAGGTGAATCTTCATCAGC }\end{array}$ & 99 & $\begin{array}{l}95^{\circ} \mathrm{C}, 5 \mathrm{~min} ; 45 \text { cycles }\left(95^{\circ} \mathrm{C}, 10 \mathrm{~s} ; 57^{\circ} \mathrm{C}, 30 \mathrm{~s} ; 72{ }^{\circ} \mathrm{C} \text {, }\right. \\
16 \mathrm{~s}) ; 72^{\circ} \mathrm{C}, 5 \mathrm{~min}\end{array}$ \\
\hline Exon2c (Ex2c) & $\begin{array}{l}\text { F: GACTTGAAGGTAGAAGTTCC } \\
\text { R: CTTGTGAGGAGTATGTGTATAC }\end{array}$ & 164 & $\begin{array}{l}95^{\circ} \mathrm{C}, 5 \mathrm{~min} ; 45 \text { cycles }\left(95^{\circ} \mathrm{C}, 10 \mathrm{~s} ; 56{ }^{\circ} \mathrm{C}, 30 \mathrm{~s} ; 72{ }^{\circ} \mathrm{C} \text {, }\right. \\
16 \mathrm{~s}) ; 72{ }^{\circ} \mathrm{C}, 5 \mathrm{~min}\end{array}$ \\
\hline Exon3a (Ex3a) & $\begin{array}{l}\text { F: CTTTCACATTCCAGTAAGTGTC } \\
\text { R: GTAAAGTGTAAGAAGTAAGTGGG }\end{array}$ & 379 & $\begin{array}{l}95^{\circ} \mathrm{C}, 5 \mathrm{~min} ; 45 \text { cycles }\left(95^{\circ} \mathrm{C}, 10 \mathrm{~s} ; 57^{\circ} \mathrm{C}, 30 \mathrm{~s} ; 72{ }^{\circ} \mathrm{C} \text {, }\right. \\
16 \mathrm{~s}) ; 72^{\circ} \mathrm{C}, 5 \mathrm{~min}\end{array}$ \\
\hline Exon3b (Ex3b) & $\begin{array}{l}\text { F: TCAAATACTGCCTGGGAAG } \\
\text { R: CTGCCATGCCTTACAGAG }\end{array}$ & 373 & $\begin{array}{l}95^{\circ} \mathrm{C}, 5 \mathrm{~min} ; 45 \operatorname{cycles}\left(95^{\circ} \mathrm{C}, 10 \mathrm{~s} ; 57^{\circ} \mathrm{C}, 30 \mathrm{~s} ; 72{ }^{\circ} \mathrm{C} \text {, }\right. \\
16 \mathrm{~s}) ; 72^{\circ} \mathrm{C}, 5 \mathrm{~min}\end{array}$ \\
\hline Exon3c $(\operatorname{Ex} 3 \mathrm{c})$ & $\begin{array}{l}\text { F: CAAACTATAATGCAGAAAGCC } \\
\text { R: GAGCCATGATTGTGCCAC }\end{array}$ & 376 & $\begin{array}{l}95^{\circ} \mathrm{C}, 5 \mathrm{~min} ; 45 \text { cycles }\left(95^{\circ} \mathrm{C}, 10 \mathrm{~s} ; 64^{\circ} \mathrm{C}, 30 \mathrm{~s} ; 72{ }^{\circ} \mathrm{C} \text {, }\right. \\
16 \mathrm{~s}) ; 72{ }^{\circ} \mathrm{C}, 5 \mathrm{~min}\end{array}$ \\
\hline \multicolumn{4}{|l|}{ B } \\
\hline Exon3b (Ex3b)-F & TCAAATACTGCCTGGGAAG & & \multirow{6}{*}{$\begin{array}{l}95^{\circ} \mathrm{C}, 2 \mathrm{~min} ; 30 \text { cycles }\left(95^{\circ} \mathrm{C}, 10 \mathrm{~s} ; 58^{\circ} \mathrm{C}, 30 \mathrm{~s} ; 72{ }^{\circ} \mathrm{C} \text {, }\right. \\
16 \mathrm{~s}) ; 72{ }^{\circ} \mathrm{C}, 4 \mathrm{~min}\end{array}$} \\
\hline Exon3b (Ex3b)-R & CTGCCATGCCTTACAGAG & 273,265 & \\
\hline ARMs C (wild) & CCTTTTGATTTTGGATAGC & & \\
\hline Exon3b (Ex3b)-F & TCAAATACTGCCTGGGAAG & & \\
\hline Exon3b (Ex3b)-R & CTGCCATGCCTTACAGAG & 273,147 & \\
\hline ARMs G (mutant) & TCCAGTAAAAAGCTGACAGC & & \\
\hline
\end{tabular}

F- forward, R- reverse.

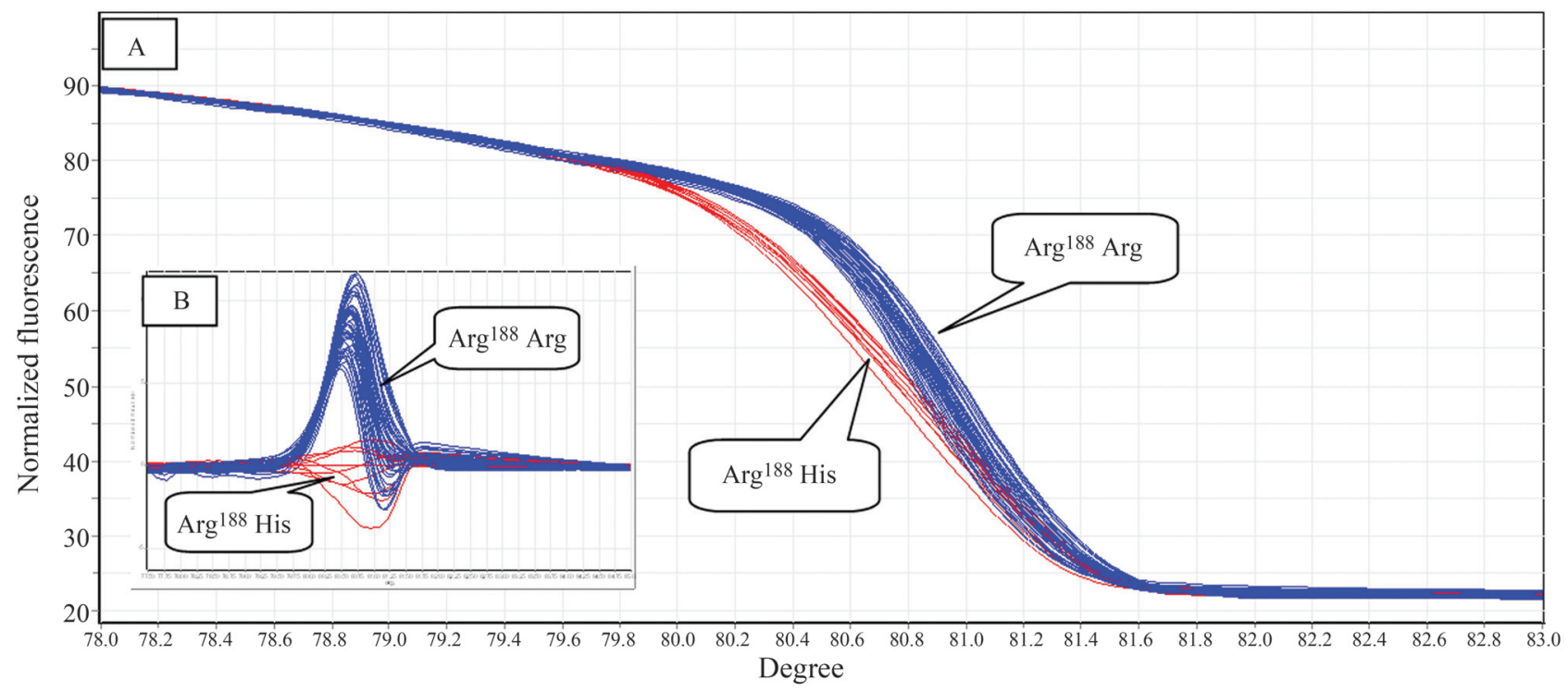

Figure 1 - (A) HRM curves for exon 3b (Ex3b) of the XRCC2 gene in patients and controls. The $\operatorname{Arg}{ }^{188}$ His genotype (red curves) was detected as a new melting curve group in a few patients and controls compared with the normal melting curves obtained for the wild type (Arg ${ }^{188}$ ) genotype (blue curves). (B) Difference graph of the HRM curves.

a single nucleotide polymorphism (SNP) in the Ex3b fragment, the samples in this group were subjected to DNA sequencing and a previously reported polymorphism (Arg ${ }^{188}$ His, rs3218536) was detected in all of them. No His/His alleles were found in the population. Table 2 sum- marizes the distributions of the allelic and genotypic frequencies in the case and control groups.

Another suspicious melting curve was identified in the Ex3b fragment and DNA sequencing confirmed a novel missense mutation (AGC $\rightarrow \mathrm{AGG}, \mathrm{Ser}^{150} \mathrm{Arg}$ ) in one sam- 
Table 2 - General characteristics of the case and control groups and the allelic and genotypic ( $\left.\mathrm{Arg}^{188} \mathrm{His}\right)$ frequencies of $\mathrm{XRCC2}$.

\begin{tabular}{lcccc}
\hline Variable & Case n (\%) & Control n (\%) & p & OR (95\% CI) \\
\hline Age (years) & & & & \\
$\leq 50$ & $44(88 \%)$ & $44(88 \%)$ & 0.383 & \\
$>50$ & $6(12 \%)$ & $6(12 \%)$ & & \\
Sex & & & & \\
Male & $12(24 \%)$ & $12(24 \%)$ & 1.000 & \\
Female & $38(76 \%)$ & $38(76 \%)$ & & \\
Genotype $\left(\operatorname{Arg}^{188}\right.$ His $)$ & & & \\
GG & $43(86 \%)$ & $45(90 \%)$ & $0.38^{\mathrm{a}}$ & 1.46 \\
GA & $7(14 \%)$ & $5(10 \%)$ & & $(0.432-4.969)^{\mathrm{b}}$ \\
Allele frequency & & & \\
G & $93(0.93 \%)$ & $95(0.95 \%)$ & $0.39^{\mathrm{a}}$ & 1.43 \\
A & $7(0.07 \%)$ & $5(0.05 \%)$ & & $(0.438-4.666)^{\mathrm{c}}$ \\
\hline
\end{tabular}

${ }^{a}$ One tailed chi-squared analysis comparing genotype distributions and allelic frequencies between cases and controls.

${ }^{\mathrm{b}} \mathrm{OR}(95 \% \mathrm{CI}) \mathrm{GA}$ to GG genotype ( $\operatorname{Arg}^{188} \mathrm{His}$ ) of $\mathrm{XRCC} 2$ for case $v s$. control groups.

${ }^{\mathrm{c}} \mathrm{OR}(95 \% \mathrm{CI}) \mathrm{A}$ to $\mathrm{G}$ allele ( $\left.\operatorname{Arg}^{188} \mathrm{His}\right)$ of $\mathrm{XRCC} 2$ for case $v$ s. control groups.

ple of the control group. No mutation was detected in the other samples screened for this mutation using ARMS.

The difference between the $\mathrm{Arg}^{188} \mathrm{His}$ and $\mathrm{Arg}^{188}$ genotypic frequencies was not significant and there was no significant association between DTC and the G and A allelic frequencies (Table 2).

\section{Discussion}

In this study, we used HRM analysis to screen for genetic mutations in the entire coding region of the $X R C C 2$ gene and examined the association between these mutations and DTC in a subpopulation from Tehran, Iran. HRM analysis is an innovative technique for genotyping that is based on DNA melting analysis such that any alteration in genotype leads to variation in the HRM curves when compared to the wild type (Montgomery et al., 2010). To our knowledge, this is the first time that the entire coding region of the XRCC2 gene has been analyzed. Two polymorphisms, CGC $\rightarrow$ CAC (Arg ${ }^{188}$ His, rs3218536) and
$\mathrm{AGC} \rightarrow \mathrm{AGG}\left(\mathrm{Ser}^{150} \mathrm{Arg}\right)$, were identified in Ex3b of the $X R C C 2$ gene. To detect the $\operatorname{Arg}^{188}$ His polymorphism we distinguished between wild homozygote $(\mathrm{G}:: \mathrm{C})$ and heterozygote (A::T, G::C) samples based on a discernible melting transition (Figure 1A).

There was no significant association between DTC and the $\mathrm{Arg}^{188} \mathrm{His}$ polymorphism and its genotypic frequency in the individuals studied (Table 2). Bastos et al. (2009) and Garcia-Quispes et al. (2011) also found no significant involvement of the XRCC2 $\mathrm{Arg}^{188} \mathrm{His}$ polymorphism in thyroid cancer in 109 (OR: 0.8, 95\%CI: 0.4-1.6) and 402 (OR: 1.12, 95\%CI: 0.80-1.59) patients, respectively. There are currently no additional data on the relationship between the XRCC2 $\mathrm{Arg}^{188} \mathrm{His}$ polymorphism and thyroid cancer.

A recent meta-analysis by $\mathrm{Yu}$ et al. (2010) reported that there was no evidence of a significant association between $X R C C 2 \mathrm{Arg}^{188} \mathrm{His}$ and the risk of breast cancer in any genetic model. A meta-analysis of three case-control studies in the United Kingdom and a family-based study in the United States found no association between a putatively functional $\mathrm{Arg}^{188} \mathrm{His}$ SNP and colorectal cancer (Curtin et al., 2009). Similarly, a meta-analysis of 16 studies compiled by the International Ovarian Cancer Association Consortium showed there was also no association between Arg ${ }^{188} \mathrm{His}$ and the risk of ovarian cancer (Pearce et al., 2009). However, the $X R C C 2 \mathrm{Arg}^{188}$ His polymorphism may be a genetic modifier for smoking-related pancreatic cancer (Jiao et al., 2008).

Alignment of the protein sequence of human XRCC2 with that of other species revealed an $\mathrm{Arg}^{188}$ His substitution in Gallus gallus and Pongo abelii (Figure 2). Furthermore, $\mathrm{Arg}^{188}$ is not present at the active site of three XRCC2 proteins. This finding suggests that the $\mathrm{Arg}^{188} \mathrm{His}$ polymorphism generated in homologous recombination repair pathway may not have severe effects on XRCC2 function and may not influence the susceptibility to cancer in humans.

We detected a novel missense mutation (AGC $\rightarrow$ AGG, Ser ${ }^{150} \mathrm{Arg}$ ) in the XRCC2 gene in one sample of the control group. In this $\mathrm{G}:: \mathrm{C}$ conversion, bases switched strands but the GC content was conserved and the melting transitions of heterozygote, wild and variant homozygotes

$\begin{array}{llll}\text { Homo sapiens (human) } & 142 & \text { SLCLLILDSLSAFYWIDRVNGGESVNLQESTLRKCSQCLEKLVNDYRLVL } & 191 \\ \text { Pan troglodytes (chimpanzee) } & 142 & \text { SLCLLILDSLSAFYWIDRVNGGESVNLQESTLRKCSQCLEKLVNDYRLVL } & 191 \\ \text { Canis lupus familiaris (dog) } & 138 & \text { SLCLLILDSLSAFYWIDRVNGGESVNLQEATLKKCAQFLEKLVNEYRLVL } & 187 \\ \text { Bos taurus (ox) } & 142 & \text { SVCLLILDSLSAFYWIDRVNGGESVNLQESTLRKCSQLLEKLVNEYRLVL } & 191 \\ \text { Mus musculus (mouse) } & 142 & \text { SLCLLIVDSLSSFYWIDRVSGGESVALQESTLQKCSQLLERLVTEYRLLL } & 191 \\ \text { Rattus norvegicus (rat) } & 142 & \text { SLCLLIVDSMSSFYWIDRVSGGESVSLQESTLQKCSQLLERLVTEYRLLL } & 191 \\ \text { Gallus gallus (chicken) } & 243 & \text { SLCLLILDSISAFYWIDRSNGGESLNSQEMNLKKCANFLEKLVREHHLVL } & 292 \\ \text { Danio rerio (zebrafish) } & 150 & \text { TLGLLVIDSISAFYWTDRFNGGESASCQEANLRKCAELLDRLRRNYGIVI } & 199 \\ \text { Macaca mulatta (rhesus monkey) } & 142 & \text { SLCLLILDSLSAFYWIDRVNGGESVNLQESTLRKCSQCLEKLVNDYRLVL } & 191 \\ \text { Pongo abelii (orangutan) } & 142 & \text { SLCLLILDSLSAFYWIDRVNGGESVNLQESTLRKCSQCLEKLVNDYHLVL } & 191\end{array}$

Figure 2 - Multiple protein sequence alignment of a selected region of Homo sapiens XRCC2 with that of other species. Highlighted amino acids represent $\mathrm{Ser}^{150}$ and $\mathrm{Arg}^{188}$ of $H$. sapiens XRCC2 compared with other species. 
were not clearly distinguishable (Cai et al., 2010). We therefore used PCR-ARMS to detect this SNP in other samples. Ser ${ }^{150}$, which is involved in the formation of the ATP binding site in XRCC2, is highly conserved among species (Figure 2). Consequently, an Arg substitution at this position (replacing a neutral amino acid by a positively charged one) would most probably affect the formation of the ATP binding site. However, protein expression studies are needed to confirm this hypothesis.

The major limitation of this study is the sample size, which may be due to lesser probability of detecting any rare mutations in smaller sample size. On the other hand, for detected SNP, the larger sample size would make the results more significant. In this regard, the coexistence of other members of the Rad51 gene family with an impaired function alongside $\operatorname{Arg}^{188} \mathrm{His}$ should be considered since these proteins are also involved in the HR repair system. For example, Bastos et al. (2009) showed that the coexistence of three or more variant alleles in the RAD51 and XRCC3 genes was associated with a significantly higher risk of DTC $(\mathrm{OR}=2.9, \mathrm{p}=0.036$; four variant alleles: adjusted $\mathrm{OR}=8.0, \mathrm{p}=0.006$ ), while no associations were observed for polymorphisms in XRCC3 alone (Bastos et al., 2009; Garcia-Quispes et al., 2011).

In conclusion, our findings indicate that there is no association between polymorphisms in the $X R C C 2$ coding region and the risk of DTC. However, further studies with a larger population are needed to confirm this conclusion. In addition, it would be prudent for other members of the Rad51 gene family also to be screened for SNPs in their coding region. Finally, HRM analysis was found to be very useful for genotyping, although it was unable to distinguish between $\mathrm{G}:: \mathrm{C}$ and $\mathrm{A}:: \mathrm{T}$ conversions because of the low melting curve transition. Other complementary methods are needed to overcome this limitation.

\section{Acknowledgments}

This research was supported by Tehran University of Medical Sciences \& Health Services (grant no. 89-0130-10489). We thank the Department of Biochemistry, Pasteur Institute of Iran for contribution in study design and HRM experiments. We also thank Dr. Anis Jafari and Mr. Naser Nejadi for editing the manuscript.

\section{References}

Bastos HN, Antao MR, Silva SN, Azevedo AP, Manita I, Teixeira V, Pina JE, Gil OM, Ferreira TC, Limbert E, et al. (2009) Association of polymorphisms in genes of the homologous recombination DNA repair pathway and thyroid cancer risk. Thyroid 19:1067-1075.

Cai Y, Yuan Y, Lin Q and Chan P (2010) Allele-specific extension allows base-pair neutral homozygotes to be discriminated by high-resolution melting of small amplicons. Anal Biochem 406:29-33.
Cui X, Brenneman M, Meyne J, Oshimura M, Goodwin EH and Chen DJ (1999) The XRCC2 and XRCC3 repair genes are required for chromosome stability in mammalian cells. Mutat Res 434:75-88.

Curtin K, Lin WY, George R, Katory M, Shorto J, CannonAlbright LA, Smith G, Bishop DT, Cox A and Camp NJ (2009) Genetic variants in XRCC2: New insights into colorectal cancer tumorigenesis. Cancer Epidemiol Biomarkers Prev 18:2476-2484.

Davies L and Welch HG (2006) Increasing incidence of thyroid cancer in the United States, 1973-2002. JAMA 295:2164-2167.

Deans B, Griffin CS, Maconochie M and Thacker J (2000) Xrcc2 is required for genetic stability, embryonic neurogenesis and viability in mice. EMBO J 19:6675-6685.

Deans B, Griffin CS, O'Regan P, Jasin M and Thacker J (2003) Homologous recombination deficiency leads to profound genetic instability in cells derived from Xrcc2-knockout mice. Cancer Res 63:8181-8187.

Garcia-Quispes WA, Perez-Machado G, Akdi A, Pastor S, Galofre P, Biarnes F, Castell J, Velazquez A and Marcos R (2011) Association studies of OGG1, XRCC1, XRCC2 and XRCC3 polymorphisms with differentiated thyroid cancer. Mutat Res 709-710:67-72.

Gatzidou E, Michailidi C, Tseleni-Balafouta S and Theocharis S (2010) An epitome of DNA repair related genes and mechanisms in thyroid carcinoma. Cancer Lett 290:139-147.

Gruver AM, Miller KA, Rajesh C, Smiraldo PG, Kaliyaperumal S, Balder R, Stiles KM, Albala JS and Pittman DL (2005) The ATPase motif in RAD51D is required for resistance to DNA interstrand crosslinking agents and interaction with RAD51C. Mutagenesis 20:433-440.

Han J, Hankinson SE, Hunter DJ and De Vivo I (2004) Genetic variations in XRCC2 and XRCC3 are not associated with endometrial cancer risk. Cancer Epidemiol Biomarkers Prev 13:330-331.

Hundahl SA, Fleming ID, Fremgen AM and Menck HR (1998) A National Cancer Data Base report on 53,856 cases of thyroid carcinoma treated in the U.S., 1985-1995. Cancer 83:26382648.

Jackson SP (2002) Sensing and repairing DNA double-strand breaks. Carcinogenesis 23:687-696.

Jemal A, Siegel R, Ward E, Hao Y, Xu J, Murray T and Thun MJ (2008) Cancer statistics, 2008. CA Cancer J Clin 58:71-96.

Jiao L, Hassan MM, Bondy ML, Wolff RA, Evans DB, Abbruzzese JL and Li D (2008) XRCC2 and XRCC3 gene polymorphism and risk of pancreatic cancer. Am J Gastroenterol 103:360-367.

Kasiulevicious V, Sapoka V and Filipaviciute R (2006) Sample size calculation in epidemiological studies. Gerontologija 7:225-231.

Leenhardt L, Grosclaude P and Cherie-Challine L (2004) Increased incidence of thyroid carcinoma in France: A true epidemic or thyroid nodule management effects? Report from the French Thyroid Cancer Committee. Thyroid 14:10561060.

Miller SA, Dykes DD and Polesky HF (1988) A simple salting out procedure for extracting DNA from human nucleated cells. Nucleic Acids Res 16:1215. 
Montgomery JL, Sanford LN and Wittwer CT (2010) Highresolution DNA melting analysis in clinical research and diagnostics. Expert Rev Mol Diagn 10:219-240.

Paques F and Haber JE (1999) Multiple pathways of recombination induced by double-strand breaks in Saccharomyces cerevisiae. Microbiol Mol Biol Rev 63:349-404.

Pearce CL, Near AM, Van Den Berg DJ, Ramus SJ, GentryMaharaj A, Menon U, Gayther SA, Anderson AR, Edlund $\mathrm{CK}, \mathrm{Wu} \mathrm{AH}$, et al. (2009) Validating genetic risk associations for ovarian cancer through the International Ovarian Cancer Association Consortium. Br J Cancer 100:412-420.

Peterson CL and Cote J (2004) Cellular machineries for chromosomal DNA repair. Genes Dev 18:602-616.

Preston DL, Ron E, Tokuoka S, Funamoto S, Nishi N, Soda M, Mabuchi K and Kodama K (2007) Solid cancer incidence in atomic bomb survivors: 1958-1998. Radiat Res 168:1-64.

Ron E, Lubin JH, Shore RE, Mabuchi K, Modan B, Pottern LM, Schneider AB, Tucker MA and Boice Jr. JD (1995) Thyroid cancer after exposure to external radiation: A pooled analysis of seven studies. Radiat Res 141:259-277.

Siraj AK, Al-Rasheed M, Ibrahim M, Siddiqui K, Al-Dayel F, Al-Sanea O, Uddin S and Al-Kuraya K (2008) RAD52 polymorphisms contribute to the development of papillary thyroid cancer susceptibility in Middle Eastern population. J Endocrinol Invest 31:893-899.

Sonoda E, Sasaki MS, Buerstedde JM, Bezzubova O, Shinohara A, Ogawa H, Takata M, Yamaguchi-Iwai Y and Takeda S (1998) Rad51-deficient vertebrate cells accumulate chromosomal breaks prior to cell death. EMBO J 17:598-608.
Sugawara N, Wang X and Haber JE (2003) In vivo roles of Rad52, Rad54, and Rad55 proteins in Rad51-mediated recombination. Mol Cell 12:209-219.

Takata M, Sasaki MS, Tachiiri S, Fukushima T, Sonoda E, Schild D, Thompson LH and Takeda S (2001) Chromosome instability and defective recombinational repair in knockout mutants of the five Rad51 paralogs. Mol Cell Biol 21:2858-2866.

Tambini CE, Spink KG, Ross CJ, Hill MA and Thacker J (2010) The importance of XRCC2 in RAD51-related DNA damage repair. DNA Repair (Amst) 9:517-525.

Thacker J (1999) A surfeit of RAD51-like genes? Trends Genet $15: 166-168$

Thompson LH and Schild D (2002) Recombinational DNA repair and human disease. Mutat Res 509:49-78.

Wolner B, van Komen S, Sung P and Peterson CL (2003) Recruitment of the recombinational repair machinery to a DNA double-strand break in yeast. Mol Cell 12:221-232.

Xiong P, Zheng R, Wang LE, Bondy ML, Shen H, Borer MM, Wei Q and Sturgis EM (2005) A pilot case-control study of gamma-radiation sensitivity and risk of papillary thyroid cancer. Thyroid 15:94-99.

Yu KD, Chen AX, Qiu LX, Fan L, Yang C and Shao ZM (2010) XRCC2 Arg188His polymorphism is not directly associated with breast cancer risk: Evidence from 37,369 subjects. Breast Cancer Res Treat 123:219-225.

Associate Editor: Jeremy A. Squire

License information: This is an open-access article distributed under the terms of the Creative Commons Attribution License, which permits unrestricted use, distribution, and reproduction in any medium, provided the original work is properly cited. 